\title{
Industrial Infrastructure of Moscow: Functional Condition and Development Opportunities
}

\author{
Davydova Olesia \\ Plekhanov Russian University of Economics, Moscow, Russian Federation \\ oadavidova@gmail.com
}

Received date: 3 March 2017; Accepted date: 6 June 2017; Published date: 26 December 2017

Accademic Editor: Yulia Vertakova

Copyright (C) 2017. Davydova Olesia. Distributed under Creative Commons CC-BY 4.0

\begin{abstract}
The article considers sectoral, regional, country and international levels of development of industrial infrastructure.The basic problems of development of industrial infrastructure in the world are analyzed.A disproportion between the construction of new facilities and the maintenance of already constructed facilities is revealed.The analysis of the influence of innovative processes in the development of industrial infrastructures through socioeconomic indicators of the regions of the Russian Federation is carried out. The focus is on the basic elements of the production infrastructure: transport and electricity.The correlation analysis of retrospective statistical data is used as the main tool. It is substantiated that it is necessary to improve the quality of infrastructure for intensifying the development of the region.

The article contains research on the state and trends of the industrial infrastructure of the city of Moscow. The main aspects of the development of the city of Moscow are considered: production, investment, consumption, finance.The peculiarities of the GRP structure of the city of Moscow are examined in contrast to other regions of the Russian Federation, as well as attracting investments in fixed assets and its distribution by industry. The factors influencing the attraction of investments into the development of industrial infrastructure in the city of Moscow are systematized.Recommendations for improving regional policy were made, a scheme for the development of industrial infrastructure in the city of Moscow aimed at involving public organizations in the management of industrial infrastructure facilities was proposed.
\end{abstract}

Keywords: innovation, territorial clusters, modernization, industrial infrastructure, region.

JEL code: R11, H54, R58

Cite this Article as: Davydova Olesia (2017)," Industrial Infrastructure of Moscow: Functional Condition and Development Opportunities ", Journal of Eastern Europe Research in Business and Economics, Vol. 2017 (2017), Article ID 762963, DOI: 10.5171/2017.762963 


\section{Introduction}

The global economic crisis has had a major impact on the role of traditional investors in infrastructure projects. On the one hand, the problems associated with the state of public finances constrain infrastructure financing from governments, on the other hand, currently banks are not prepared to provide long-term financing at affordable rates.

According to Mark Zandi, chief economist Moody's Economy, public investment in infrastructure stimulates private investment: invested in infrastructure projects every dollar produces a multiplicative effect in the amount of \$ 1.59. The most significant contribution to stimulating the economy is due to the development of transport and energy infrastructure, which is elements industrial infrastructure.

However, worldwide there is a global moral wear of the existing production infrastructure. This contributes to the constant growth in population, which leads to more intensive use of existing infrastructure.

To this must be added the fact that new technologies are developed in short period and the innovation process began in the last decades, and industrial infrastructure has been formed in the past century, which in varying degrees, showing feature of deterioration

\section{Reseach question}

According to a report published at the World economic forum, insufficient funding of infrastructure is among the most serious economic risks for all countries, because the state of the infrastructure depends on the well-being and sustainable development of any branch region.

Experts of the company McKinsey defined that to reduce costs by $40 \%$ with the same amount of infrastructure, or in other words to increase the efficiency of infrastructure by $60 \%$, management of infrastructure is required by the wider application of best practices in the field of selection and implementation of new infrastructure projects and obtain better value from existing infrastructure [8].

Infrastructure costs are constantly falling. In the 50-60-s of the last century they were in the USA $3-4 \%$ of GDP in 2013 to $2.4 \%$. The American Society of Civil Engineers set a General rating of D - "collapsing" infrastructure. State about $30 \%$ of roads in the United States does not coincide with regulatory requirements. Repairing all worn-out bridges will require $\$ 160$ billion. Rolling blackouts and other deficiencies of the U.S. electrical grid costs the economy \$ 80 billion per year. Only repair of existing infrastructure of the USA in the next 5 years, you must allocate \$ 2.2 trillion (excluding the cost of construction of new facilities). Today the United States spends on infrastructure maintenance $2.4 \%$ of GNP. For comparison, China's spend on infrastructure amounts to $9 \%$ of GDP. According to analysts, only about half of the funds in the 2008-2009 year, the Chinese government spent to do the necessary infrastructure. In 2011, about $65 \%$ of the 180 airports were unprofitable, the total amount of losses amounted to 2 billion yuan [8].

The results of the analysis of the infrastructure of Japan in 2013, Professor University of the Toe, Nemoto Yuji also proposed to limit investments in new infrastructure and to invest in maintenance and upgrade worn-out infrastructure [9].

According to joint report organizations Smart Growth America and Taxpayers for Common Sense «Repair Priorities 2014», current repair expenses for maintenance of transport infrastructure in good condition amount to 16.5 billion dollars whereas it takes almost three times more than 45.2 billion dollars. [13].

According to the report prepared for the Federation of the Canadian Municipalities in November 2007, a lack of investment in repair and restoration service of urban transport systems, built primarily in the

Davydova Olesia (2017), Journal of Eastern Europe Research in Business and Economics, DOI:10.5171/2017.762963 
1960s, has increased from 3.05 billion. in 1996, to 22.8 billion dollars. in 2007, [11].

Professor of Economics, brown University Matthew Turner and Professor at the Wharton business school of the University of Pennsylvania Gilles Duranton, in the analysis of data characterizing the traffic in the continental United States from 1983 to 2003, confirmed the fundamental law of road congestion, formulated by Anthony Downs in 1962: the extension of interstate highways leads to a proportional increase in traffic [4].

One of the examples of how it affects the expansion of roads on the movement and became a recently completed project to increase interstate 405 in Los Angeles (Sepulveda Pass Improvement Project). For its implementation took five years and the cost amounted to more than $\$ 1$ billion. However, carried out after opening the upgraded highway, studies have shown that the traffic on it has not improved, but rather became even a little worse than before the expansion [7].

In the Republic of Korea in 1999-2006 was conducted the feasibility study for the 290 projects for a total value of which reached 144.9 trillion won. The result of 129 projects (44\%) was considered infeasible and 72.9 trillion won of the budget was allocated to other purposes [10].

of fundamental importance is the ratio between the new infrastructure building and repair of the existing network. Methods of assessing the quality of the infrastructure and technologies "depreciation quality" are virtually nonexistent.

At the present time there was an obvious disproportion between the construction of new infrastructure and maintenance of already built infrastructure due to low investment in the operation of infrastructure facilities. Earlier, a similar policy of the USSR led to the complete obsolescence of the infrastructure and reduced competition in the country, and as a consequence of the collapse of the Soviet Union.
Given that cities are focal points for the development of territories and countries, in their study based on the experience of one of the complex regions of the Russian Federation - Moscow city - are considered an opportunity of the path of development of industrial infrastructure.

Therefore, development should seek new ways of infrastructure development and patterns of development of cities, which can serve as focal points for the development of the region as a whole.

The practical importance of research consists in the possibility to use the conclusions contained therein, certain provisions, database of information, recommendations, applied for the formation of regional policy.

\section{Reseach Design and Methodology}

The Modern Russia is characterized by really insufficient development of regional infrastructure from the growing needs of the economy. The level of provision of infrastructure in regions of Russia is of the US level in the interval of 6.7 to $25.2 \%$ [12].

The deterioration of transport and electropower infrastructure amounts to about $40-60 \%$ depending on population and climatic conditions of the regions of the Russian Federation.

The basic state policy of the Russian Federation consists of improving access to infrastructure. The result of advancement of normative-legal base and implementation of the road map for the implementation state policy in this direction was to improve the position of the Russian Federation (with 120 positions in 2011 to 51 positions in 2015) in the Doing Business rating. The evaluation was conducted by aggregating the results of the two cities - Moscow and Saint Petersburg [5].

The infrastructure is formed and developed depending on the specifics of the region: the size of territory, population density, climatic conditions, availability of 
megapolis functioning of industries and other proceedings [1]. In this regard, on the basis of official statistical data on socioeconomic indicators of the city of Moscow, will developed approaches to the development of industrial infrastructure.

In contrast other industrial cities of the Russian economy which are based on industrial enterprises, in the structure of GRP of Moscow the largest proportion in trade, including trade of fuel and energy resources. In second place is the activities related to business services, scientific research and development, and information technology. Industry takes the third place in terms of value added. The structure of GRP of Moscow is similar to the structure of GRP of the world's cities. Industry of Moscow is mostly represented by manufacturing industries (share of GRP $13 \%$ ), whose growth for 2014 was $1.4 \%$ .The volume of investments in fixed capital despite the financial crisis is fairly stable in the city of Moscow and typical for the Russian Federation as a whole (figure № 1).

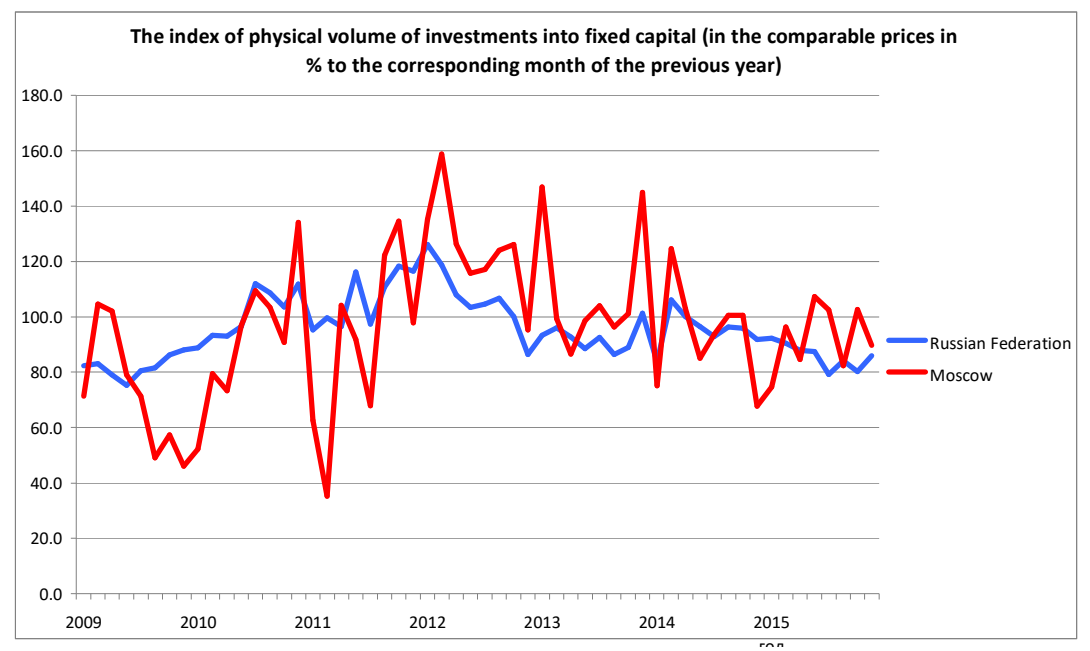

Figure 1: The index of physical volume in Russia and Moscow in 2010-2014

Resource: Federal State Statistics Service of the Russian Federation

The volume of investment in industrial infrastructure is on average $14-15 \%$ in the structure of investment and $3 \%$ of GRP (table 1).

The increased output of goods and services branches of the city economy, which occupies the main share in the GRP structure, as well as increased investment in productive infrastructure, are allowed to assess positively the result of the year of 2014 (figure № 2).

For this assessment graphs were constructed index of physical volume of

\begin{abstract}
gross regional product, industrial production index and volume of investments in production infrastructure. Given that these indicators have a different scale, the scale on different sides of the coordinate axis Y was used. On the left is the scale of the index of the physical volume of the gross regional product, the index of industrial production, on the right is the volume of investments in the industrial infrastructure.
\end{abstract}




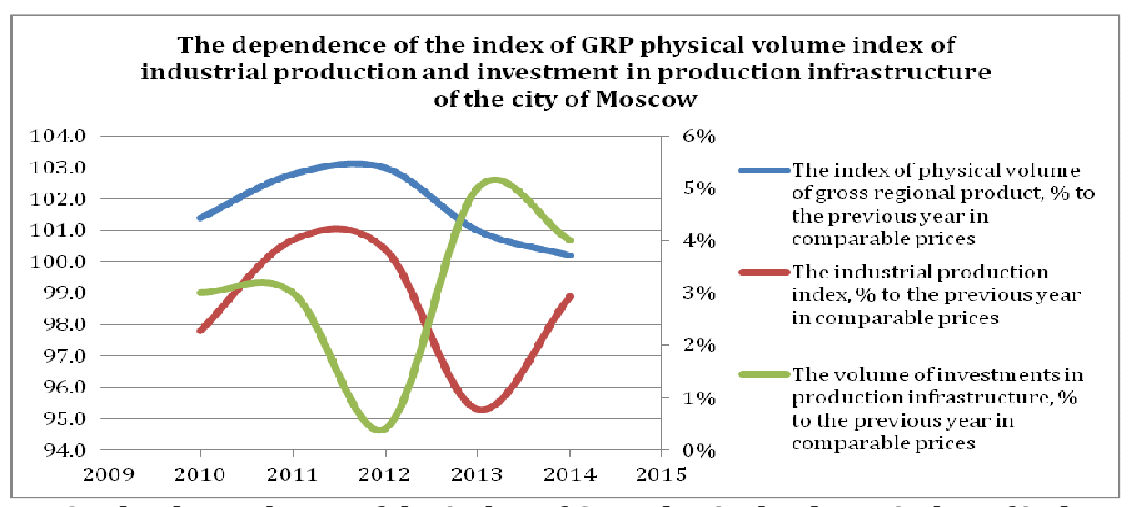

Figure 2: The dependence of the index of GRP physical volume index of industrial production and investment in production infrastructure of the city of Moscow Resource: Federal State Statistics Service of the Russian Federation 
Table 1: The volume of investments in fixed capital due to all funding sources and distribution by industry in the city of Moscow

\begin{tabular}{|c|c|c|c|c|c|c|}
\hline \multirow[b]{2}{*}{ Indicators } & \multirow{2}{*}{$\begin{array}{c}\text { Unit of } \\
\text { measurement }\end{array}$} & \multicolumn{5}{|c|}{ Report } \\
\hline & & 2010 & 2011 & 2012 & 2013 & 2014 \\
\hline $\begin{array}{l}\text { Gross regional product (in } \\
\text { basic prices of } \\
\text { corresponding years) }\end{array}$ & $\begin{array}{l}\text { thousand million } \\
\text { rub }\end{array}$ & 8400 & 9950 & 107000 & 11800 & 12800 \\
\hline Investments in fixed capital & $\begin{array}{c}\text { in prices of } \\
\text { respective years; } \\
\text { thousand million } \\
\text { rub }\end{array}$ & 700,0 & 850,0 & 1200,0 & 1400,0 & 1500,0 \\
\hline $\begin{array}{l}\text { The volume of investments } \\
\text { in fixed capital due to all } \\
\text { funding sources }\end{array}$ & $\begin{array}{l}\text { thousand million } \\
\text { rub }\end{array}$ & 540,0 & 660,0 & 820,0 & 1000,0 & 1000,0 \\
\hline Transport and link & $\begin{array}{c}\text { thousand million } \\
\text { rub }\end{array}$ & 124,0 & 228,0 & 304,0 & 435,0 & 380,0 \\
\hline $\begin{array}{l}\text { The percentage of } \\
\text { investment in transport and } \\
\text { link }\end{array}$ & $\begin{array}{l}\text { thousand million } \\
\text { rub }\end{array}$ & $22,96 \%$ & $34,55 \%$ & $37,07 \%$ & $43,50 \%$ & $38,00 \%$ \\
\hline $\begin{array}{l}\text { The percentage of } \\
\text { investment in transport and } \\
\text { link from GRP }\end{array}$ & $\begin{array}{l}\text { thousand million } \\
\text { rub }\end{array}$ & $1,48 \%$ & $2,29 \%$ & $0,28 \%$ & $3,69 \%$ & $2,97 \%$ \\
\hline $\begin{array}{l}\text { Production and distribution } \\
\text { of electricity, gas and water }\end{array}$ & $\begin{array}{l}\text { thousand million } \\
\text { rub }\end{array}$ & 88,0 & 100,0 & 110,0 & 137,0 & 135,0 \\
\hline $\begin{array}{l}\text { The percentage of } \\
\text { investments in the } \\
\text { electricity, gas and water } \\
\text { from the total investment }\end{array}$ & $\begin{array}{l}\text { thousand million } \\
\text { rub }\end{array}$ & $16 \%$ & $15 \%$ & $13 \%$ & $14 \%$ & $14 \%$ \\
\hline
\end{tabular}




\begin{tabular}{|l|c|r|r|r|r|}
\hline $\begin{array}{l}\text { The percentage of } \\
\text { investment in utilities from } \\
\text { GRP }\end{array}$ & $\begin{array}{c}\text { thousand million } \\
\text { rub }\end{array}$ & $1 \%$ & $1 \%$ & & \\
\hline $\begin{array}{l}\text { The total percentage of } \\
\text { investment in transportation } \\
\text { and energy from GRP }\end{array}$ & $\begin{array}{c}\text { thousand million } \\
\text { rub }\end{array}$ & & & $1 \%$ & \\
\hline
\end{tabular}

Resource: Federal State Statistics Service of the Russian Federation

Table 2: The Spearman correlation matrix for the variables submitted for the development of the forecast of socio-economic development in the Russian Federation for the city of Moscow

\begin{tabular}{|c|c|c|c|c|c|c|c|c|c|}
\hline Variables & GRP & Square & $\begin{array}{l}\text { The } \\
\text { population }\end{array}$ & $\begin{array}{l}\text { The length } \\
\text { of roads }\end{array}$ & $\begin{array}{l}\text { Emissions of } \\
\text { polluting } \\
\text { substances } \\
\text { into the } \\
\text { atmosphere } \\
\end{array}$ & $\begin{array}{l}\text { Discharge of } \\
\text { polluted } \\
\text { wastewater } \\
\text { into surface } \\
\text { water bodies }\end{array}$ & $\begin{array}{l}\text { The } \\
\text { production } \\
\text { of } \\
\text { electricity }\end{array}$ & $\begin{array}{l}\text { Electricit } \\
\text { y } \\
\text { consumpt } \\
\text { ion } \\
\end{array}$ & $\begin{array}{l}\text { The share of } \\
\text { organization } \\
\text { s } \\
\text { implementin } \\
\text { g } \\
\text { technologica } \\
\text { l innovation }\end{array}$ \\
\hline GRP & 1 & & & & & & & & \\
\hline Square & $-0,100$ & 1 & & & & & & & \\
\hline The population & 0,918 & $-0,211$ & 1 & & & & & & \\
\hline $\begin{array}{l}\text { The length of } \\
\text { roads }\end{array}$ & $-0,217$ & 0,247 & 0,020 & 1 & & & & & \\
\hline $\begin{array}{l}\text { Emissions of } \\
\text { polluting } \\
\text { substances into } \\
\text { the atmosphere }\end{array}$ & $-0,031$ & 0,497 & 0,032 & 0,392 & 1 & & & & \\
\hline $\begin{array}{l}\text { Discharge of } \\
\text { polluted } \\
\text { wastewater into } \\
\text { surface water } \\
\text { bodies }\end{array}$ & 0,601 & $-0,196$ & 0,782 & 0,036 & 0,156 & 1 & & & \\
\hline
\end{tabular}




\begin{tabular}{|l|r|r|r|r|r|r|r|r|}
\hline $\begin{array}{l}\text { The production } \\
\text { of electricity }\end{array}$ & $-0,631$ & 0,250 & $-0,530$ & 0,183 & 0,311 & $-0,305$ & \\
\hline $\begin{array}{l}\text { Electricity } \\
\text { consumption }\end{array}$ & 0,595 & 0,113 & 0,693 & 0,269 & 0,685 & 0,686 & $-0,165$ & \\
\hline $\begin{array}{l}\text { The share of } \\
\text { organizations } \\
\text { implementing } \\
\text { technological } \\
\text { innovation }\end{array}$ & & & & & & & \\
\end{tabular}

Resource: Calculations of the author 


\section{Result}

The condition for the development of modern cities is the formation of an innovative sector. The innovate economy is appearing in a post-industrial shift, which marked the transition from raw material production to the production of information and knowledge. Statistical indicators evidently show the growth of this sector in all countries of the world, even in times of crisis.

Analysts of Barclays point out that the introduction of innovative technologies in the production infrastructure leads to the economic growth of the region.

For searches and assessment of the relationships of socio-economic indicators, the author used correlation analysis that allows to quantify the relationship between indicators.

In the correlations between the variation of dependent and independent characteristics, there is no complete correspondence, the effect is only average for the data of mass observation One of the main tasks of correlation analysis is to determine the influence of factors on the magnitude of the resultant variable (in absolute terms).

The author has conducted analysis of the socio-economic indicators of the economy of 89 regions of the Russian Federation in the period from 2010 to 2014 .

The statistical processing of the initial data were performed using nonparametric methods of analysis - rank correlation rsSpearman, because for most variables the normality of distribution is missing. A significant correlation is established in accordance with the scale of Chedoke $(0,5 \leq \mathrm{ABS}(\mathrm{r}) \geq 0,7)$.

On the basis of the obtained data (table 2), a significant contribution to the GRP provides innovation, ecology and electropower industry. While today, electropower and transport infrastructure in the city of Moscow have a weak relationship with innovation.

The existing fragmentation in the region of environmental, infrastructure and production processes leads to an overestimation of the cost of construction of infrastructure projects. According to Rosfinnadzor, the cost of construction is overstated by $40 \%$ [5].

Using analytical tools, it was concluded that a significant contribution of public investment to consider the processes in absolute terms (figure № 3) is determined not as much basic demand, as the disunity of the budget investment in the projects in the field of environment, development of industrial infrastructure and production.

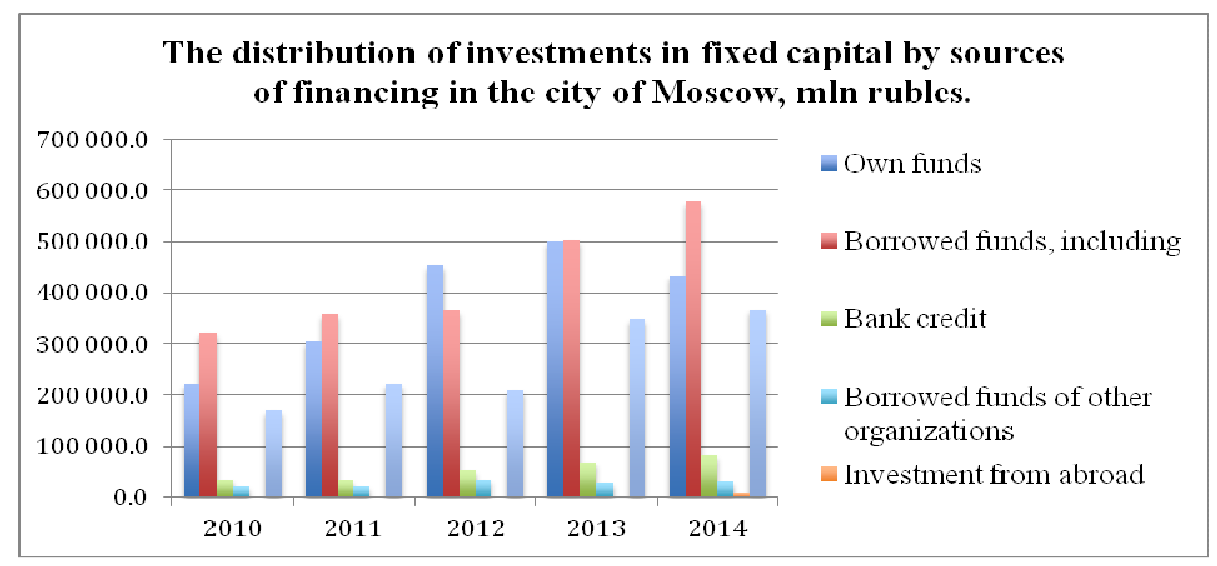

Figure 3: The distribution of investments in fixed capital by sources of financing in the city of Moscow

Davydova Olesia (2017), Journal of Eastern Europe Research in Business and Economics, DOI:10.5171/2017.762963 
Imbalances in the development of innovation environment and infrastructure can eliminate through reference points of growth of regional clusters. The main task of the cluster is technology transfer, the formation of new activities, creating logistical and financial base for the development of small and medium enterprises and transferring them to the market.

In the opinion of the author, clusters are one of the ways of redressing the imbalance between the construction of new infrastructure projects and a deterioration of the infrastructure in conditions of limited financial resources.

The experience of the city of Moscow on the formation of clusters is unique, in connection with the peculiarity of the industrial environment formed on the basis of structural readjustment of the Russian economy at the end of the 20th century.

Changes in the structure of industries in manufacturing, the decline in industrial production in the late XX century - early XXI century caused the withdrawal of large industrial complexes outside the city. On the vacant area of around 7.7 thousand ha (16\% of the area of Moscow), it was accommodated facilities office-trade and other purposes with a short payback period and high rate of return. In addition, the absence of restraining factors led to a chaotic development of the liberated territory and the use of the remaining dilapidated buildings not for their intended purpose.

However, the concentration of defense enterprises, scientific research institutes and higher education institutions, small and medium businesses, interdisciplinary industrial infrastructure of the city of Moscow have created the preconditions for the application of cluster policy, the first generation of bodies of Executive power on the territory of the city of Moscow through the creation of industrial complexes and industrial parks.

The vast majority of real estate was owned or lease by the private commercial organisations. Creation of clusters in the city occurred due to the implementation of urban planning projects - definition of the functional purpose of the future of real estate through the development of projects-plan, available production areas on the basis of the approved master plan and its consideration at a public hearing.

The Government of Moscow used the experience of Singapore, which has mastered the 7,100 hectares of industrial areas and built about 3.2 million square meters of production area and is actively developing special clusters, in which endusers will be provided with access to the required services, production and economic resources.

Currently, a positive example was the experience of the city of Barcelona, which has not gone the way of most major European cities and in part the complete withdrawal of industry from the territory. The project 22@Barcelona provides for the redevelopment of old industrial areas to create a varied environment where productive spaces coexist with educational and scientific research, as well as residential areas, green areas, etc. In this project developed a new various effective ecologic and economic development model that aims to ensure balance between the different functions. For this project, were created engineering and construction companies acting as partners of the credit institutions. Their profit margin is on average $12 \%$, while comparable U.S. companies - 7\%.

Examples of reconstruction of the existing infrastructure based on clusters in Moscow are the establishment of technoparks 20 and 22 transport hubs with the objects of social and industrial buildings in old industrial areas. However, for the economic growth of the metropolis and the number of completed projects is still insufficient, despite their the large scale.

\section{Discussion and conclusion}

The most important and complex problems in infrastructure development can be solved only in close cooperation between 
society and state. In Russia, there is a practice to solve actual issues associated with the development of infrastructure in the region with the participation of local communities. Basically the practice has developed in the design and planning but not in project management.

In General, the problem of development of industrial infrastructure concludes to its strategic and monopolistic character: joint stock companies with a larger share of state participation (government corporation), limitation of external financing in modern conditions, limited public funds for infrastructure development.

For example, the market entry of the investment infrastructure projects in the Russian Federation is limited, the participation of authorized international Bank in financing infrastructure projects can be implemented on the basis of intergovernmental agreements with at least 30\% share of the Russian Federation in the capital of international financial institution.

J. Fourier argues that the infrastructure in one way or another inherent properties of capital and publicity, which allows us to talk about the need to apply depreciation charges on roads and energy networks [6].

To attract private investors to develop industrial innovation infrastructure on the basis of clusters, it is necessary to develop new methodological principles of management with using publicity.

In recent years, the organization of work for the infrastructure services on the principles of state-private partnership is considered more effective than state management [3]

One of the most successful forms of PPP is the establishment of special project company (SPV - Special Purpose Vehile). The key advantage of the SPV is that the specialized company can do a project and may not enter into transactions that are not associated with the project. As security for the repayment of borrowed funds and the operation of the project will be only of either having the assets of the initiator of the project, or future income from the activities of a specialized design company. This fact reduces the risks of bankruptcy or voluntary liquidation of the company to a minimum, which is attractive for long-term projects. However, this approach did not fully implement the principle of publicity.

In the opinion of the author, active participation as owners and not mediocre users, including public organizations in the implementation and management of infrastructure projects on the territory of the clusters in the classical scheme of the PPP model with financial leadership will solve the problem, the constraints of financial resources and the relationship between investment in reconstruction of old facilities or the construction of new infrastructure.

\section{Acknowledgements}

The author is grateful to L.N. Chainikova doctor of Plekhanov Russian University of Economics and I.B. Burakova - Head of Department of training of scientific personnel of Plekhanov Russian University of Economics - for valuable comments. The author thanks Moscow City Investment Agency and Department of Science, Industrial Policy and Entrepreneurship of Moscow for research assistance.

\section{References}

1. Aksenov, K. E. (2014), 'Trends in the development of major post-socialist cities: is there a unique universal? (on example of St. Petersburg),' Modern productive forces, 3, 22-36.

2. Belova T. D (2015), 'Typology of regions by the key indicators of energy efficiency,' Vestnik IGEU, 4, 70-75.

3. Damon, D (2003), 'Public, prive: concilier perfomance et croissane'.Problemes economique, 2836, 18-23

4. Duranton, G., Turner, M., Matthew A. (2011). 'The Fundamental Law of Road

Davydova Olesia (2017), Journal of Eastern Europe Research in Business and Economics, DOI:10.5171/2017.762963 
Congestion: Evidence from US Cities'. American Economic Review. [Online], [Retrived April 17, 2017], http://pubs.aeaweb.org/doi/pdfplus/10.1 257/aer.101.6.2616.

5. Federal Highway Administration's Highway Statistical Series, for years 20082015. [Online], [Retrived April 17, 2017], http://www.gks.ru/

6. Fourie, J., (2006), 'Economic infrastructure: a review of definitions, theiry and empirics'. South African Journal of Economics, 74, 530-556.

7. Gropman, A., (2015), '\$1.1 Billion and Five Years Later, the 405 Congestion Relief Project is a Fail'. L.A.Weekly. [Online], [Retrived April 17, 2017], http://www.laweekly.com/news/11billion-and-five-years-later-the-405congestion-relief-project-is-a-fail5415772 .

8. McKinsey Global Institute, (2013), 'Infrastructure Productivity: How to Save \$1 Trillion a Year, [Online], [Retrived April 17 , 2017], http://www.mckinsey.com/insights/engin eering_construction/infrastructure_ productivity

9. Nemoto Yūji (2013), 'Avoiding an Infrastructure Crisis' Nippon Communications Foundation. [Online], [Retrived April 17, 2017], http://www.nippon.com/ru/currents/d00 068/?pnum $=2$

10. Hyeon PARK, (2007), 'Preliminary Feasibility Study (PFS): Performance and Challenges,' Public and Private Infrastructure Investment Management Center. [Online], [Retrived April 17, 2017], http://siteresources. worldbank.org/PSGLP/Resources/41Park. pdf.

11. Saeed Mirza, (2007), 'Danger Ahead: the Coming Collapse of Canada's Municipal Infrastructure', A Report for the Federation of Canadian Municipalities. [Online], [Retrived April 17, 2017], https://www.fcm.ca/Documents/reports/ Danger_Ahead_The_coming_collapse_of_Ca nadas_municipal_infrastructure_EN.pdf.

12. Shapkin, I. N., Blinov, A. O.,Kester, J. M. (2005) Management of regional economy, KnoRus, Moscow.

13. Smart Growth America and Taxpayers for Common Sense. (2011). Repair Priorities: Transportation spending strategies to save taxpayer dollars and improve roads. [Online], [Retrived April 17, 2017],http://www.smartgrowthamerica.or g/documents/repair-priorities-2014.pdf 